\title{
Analysis Of Economic Efficiency Of Egg Production In Imo State (Stochastic Frontier Approach)
}

\author{
N. C. Ehirim \\ Department of Agricultural Economics, \\ Federal University of Technology, Owerri. \\ U. A. Essien \\ Department of Agricultural Economics, \\ Federal University of Technology, Owerri. \\ E. Ikheloa \\ Department of Agricultural Economic, \\ Ambrose Ali University, Ekpoma Edo State \\ E. U. Nwachukwu \\ Department of Agricultural Economics, \\ Federal University of Technology, Owerri.
}

\begin{abstract}
The study applied a stochastic frontier cost function to analyze economic efficiency of poultry egg farmers and ascertained variation in economic efficiency due to inefficiency effects on egg production in Imo State. Multi-stage sampling was adopted to select 240 poultry egg farmers and data was analyzed using Stochastic Frontier Model. Flock size, costs of drugs and capital (depreciation) were significant factors of cost efficiency of the poultry egg farmers. The sigma squared $\left(\sigma^{2}\right)$ of 0.001 for the poultry farmers were statistically significant at $1 \%$ showing a goodness of fit of the model. The variance ratio (y) estimated as 0.65 for the farmers were significant at $1 \%$ level which implied that $65 \%$ variations in the cost of production of the poultry egg farmers were due to the inefficiency factor $(\mu \mathrm{i})$. The mean economic efficiency was 0.560 and ranges between 0.224 and 0.987 . The coefficients of age of farmers and household size were positive while coefficients of years of access to credit, farming experience and flock size were negative and significant at $1 \%$ level of significance on economic inefficiency of egg producers. It can therefore be recommended that capital should be channeled to commercial poultry production through the provision of macro-credits and formulation of policies and programmes by the Government to direct financial institutions to grant a definite reasonable proportion of loan-able funds to commercial poultry farmers and Potent medicine and vaccine should be provided in sufficient quantities, easily accessible at cheaper costs.
\end{abstract}

Keywords: Egg production, Economic Efficiency, Stochastic Frontier Approach

\section{INTRODUCTION}

The inability of the agriculture to produce quality food for the ever-increasing population seems to be the most worrisome situation in Nigeria (Conroy, 2005). The Federal Government of Nigeria (FGN) had tried in the past to offset the huge deficit in animal protein consumption by embarking on massive importation of chilled beef and chickens (Adedeji et.al., 2013), which is counter-productive to domestic production hence, the recent ban on importation of frozen 
poultry products resulting in positive growth of poultry industry by 10.3 percent as compared to 0.3 percent in 2003 (Ojo and Afolabi, 2009).

However, the need to meet protein requirement from domestic sources demands intensification of production of meat and eggs, derived from prolific animals like poultry birds. Various advantages of poultry production include shorter life cycle, more prolific than large livestock, technically easy venture and cheap sources of animal protein such as milk, poultry, egg, beef, pork and mutton. In fact, Poultry egg is the most nutritious and complete food known to man (Ali, 2000). Nutritionally, daily consumption of egg supplies proteins, fats, vitamins and minerals in human diet. It also contains a trace of carbohydrate, adjudged to be a better replacement for meat as itcontains all essential amino acids, in adequate proportionrequired by the body for growth and repair, good source of vitamin $A, B_{1}, B_{2}$ and $D$ with minerals such as $\mathrm{Ca}$, Fe and $\mathrm{P}$ (Adetimirin, 2000).However, in recent years, rate and level of performance in the poultry industry has fallen below expectation as a result of high feed cost arising from fluctuations in feed supplied, rising prices of ingredients, poor feed quality (Adulterated feed) and most importantly inefficiency in production. The net effect of all these are capacity underutilization, curtailment of planned expansion programs and in extreme cases liquidation and loss of business. These associated problems result in poor production leading to widening supply - demand gap; attendant high market price of egg which is far reaching to ordinary Nigerians and achieving food security and alleviating poverty becomes a herculean task.

In the light of the above maladies facing the poultry production in the country, it then becomes imperative to quantitatively measure the current level and determinants of egg production efficiency in order to formulate policy options for raising the present level of efficiency given the fact that efficiency of production is directly related to the overall productivity of the agricultural sector. The measurement of farm efficiency is an important area of research both in the developed and developing world (Bimunote, et. al. 2008). Efficiency is an important factor of productivity growth especially in developing agriculture where resources are meager which is associated with the possibility of farms producing a certain optimal level of output from a given level of resources or certain level of output at least cost. The main objective of this study is therefore to analyze economic efficiency of poultry egg farmers and ascertained variation in economic efficiency due to inefficiency effects on egg production in Imo State.

\section{Study Area}

\section{MATERIALS AND METHODS}

This study will be carried out in Imo State, Imo State is one of the Southeast states in Nigeria, the state is located in the South-Eastern Zone of Nigeria (within the rainforest zone) and lies within latitudes $5^{0} 40^{1}$ and $7^{0} 5^{l}$ North and longitudes $6^{0} 35^{l}$ and $8^{0} 30^{1}$ east. The State covers a land area of $7,480 \mathrm{~km}^{2}$ with a population of $3,939,899$ people (NPC, 2006). The state is divided into three main agricultural zones, namely Owerri, Okigwe and Orlu. It is further divided into 27 local government councils. The state is characterized by tropical climate with high humidity and temperatures that range between $1500 \mathrm{~mm}$ to $2300 \mathrm{~mm}$ and $34^{\circ} \mathrm{C}$ to $37^{\circ} \mathrm{C}$ respectively. The climate of the state also supports poultry production and other livestock such as sheep, goats, fishes and pigs.

\section{Sampling Techniques}

The data used were collected through multi- stage sampling techniques. In the first stage, two Local Government Areas (L.G.As) were randomly selected from each of the three agricultural zones in the state. In the second stage, two communities were randomly selected from each L.G.As. In the third stage, two villages were selected from each community and a random selection of ten poultry farmers were selected from each village to 240 poultry farmers 
interviewed for the study, however, 235 questionnaires were found valid and used for the analysis. Data collection was done by means of structured questionnaire using interview methods for those who could neither read nor write as well as those who were too busy to fill questionnaire themselves while some readily filled theirs.

\section{Methods of Data Analysis}

Data was analyzed using Descriptive statistics and Stochastic Cost Frontier Model. Stochastic cost frontier model was used to analyze individual farmers' economic efficiency level because it overcomes the limitation of the ordinary least squares (OLS) by providing numerical measures of their cost efficiencies.

\section{Analytical Techniques of the Stochastic Cost Function}

The cost efficiency was measured using stochastic (Cobb Douglas) cost frontier function in line with Ogundari (2006) and specified explicitly as;

$$
\operatorname{Ln} C i=b o+b_{1} Q^{*}+b_{2} L n q_{1}+b_{2} L_{n} q_{2}+b_{3} \operatorname{Lnq}_{3}+b_{4} L_{n q}+b_{5} \operatorname{Lnq}_{5}+(V i+U i)
$$

where $\mathrm{C}$ is total input costs of the ith farm, $\mathrm{Q}^{*}$ is the total egg production, $\mathrm{q}_{1}$ is amount spent on birds in naira per bird, $\mathrm{q}_{2}$ is price of feed in naira per $\mathrm{kg}, \mathrm{q}_{3}$ is average wage rate in naira per manday, $\mathrm{q}_{4}$ is price of vaccine/medication in naira per Litre, $\mathrm{q}_{5}$ is depreciation on implements in naira, bo is intercept, $b_{1}-b_{5}$ are parameters to be estimated, $V_{i}$ is error term not under the control of poultry farmers while $U_{\mathrm{i}}$ is error term under the control of poultry farmers.

However, the normalized cost function was derived by dividing through by unit price of point of layer birds stocked $\left(\mathrm{q}_{1}\right)$ which gives:

$\operatorname{Ln}\left(\mathrm{Ci} / \mathrm{q}_{1}\right)=\mathrm{bo}+\mathrm{b}_{1}\left(\mathrm{Q}^{*} / \mathrm{q}_{1}\right)+\mathrm{b}_{2} \operatorname{Ln}\left(\mathrm{q}_{2} / \mathrm{q}_{1}\right)+\mathrm{b}_{3} \operatorname{Ln}\left(\mathrm{q}_{3} / \mathrm{q}_{1}\right)+\mathrm{b}_{4} \operatorname{Ln}\left(\mathrm{q}_{4} / \mathrm{q}_{1}\right)+\mathrm{b}_{5} \operatorname{Ln}\left(\mathrm{q}_{5} / \mathrm{q}_{1}\right)+(\operatorname{Vi}+$ Ui)..... (2)

The estimate was done with the method of maximum likelihood approach using the computer program, Frontier 4.1 as used by Coelli (1996). The software generated the cost efficiency score for each poultry farmer which measures their level of inability to attain frontier cost efficiency. However, estimated cost efficiency (CE), has an inverse relationship with Economic Efficiency (EE) (Ogundari, 2006). Hence, farm -level economic efficiency (EE) was obtained using the relationship in equation (3):

$\mathrm{EE}=1 /$ Cost efficiency (CE) as obtained from the eqn (2)

Also note that inefficiency $\left(\mathrm{U}_{\mathrm{i}}\right)$ is given as:

$+\mathrm{U}_{\mathrm{i}}=1-\mathrm{EE}$

The multiple regression analysis was used to isolates the determinants of the economic inefficiency. The efficiency scores from equation (4) were regressed against the farm specific factors to obtain the determinants for inefficiency.

$\operatorname{Exp}\left(+U_{i}\right)=K_{0}+K_{1} Z_{1}+K_{2} Z_{2}+K_{3} Z_{3}+K_{4} Z_{4}+K_{5} Z_{5}+K_{6} Z_{6}+K_{7} Z_{7}+K_{8} Z_{8}+K_{9} Z_{9}+E i \ldots$

where, Exp $\left(+U_{i}\right)$ is the inefficiency score of the farmer, $Z_{1}$ is the age (years), $Z_{2}$ is farm size (number of P.O.L birds), $\mathrm{Z}_{3}$ is level of education (No. of years spent in school), $\mathrm{Z}_{4}$ is farming experience (years), $Z_{5}$ is extension contact (No. of visits), $Z_{6}$ is credit access (dummy, 1 if the 
farmer has access to credit, zero if otherwise), $\mathrm{Z}_{7}$ is co-operative society membership (dummy, 1 if the farmer belongs to a co-operation society or farmers' association, zero if otherwise), $Z_{8}$ is household size (No. of persons), $Z_{9}$ is gender (dummy, 1 for male, zero for female), $E_{i}$ is error term, $\mathrm{K}_{0}$ is intercept while $\mathrm{K}_{0}-\mathrm{K}_{9}$ are regression parameters to be estimated. The a priori expectation is that $\mathrm{K}_{2}, \mathrm{~K}_{3}, \mathrm{~K}_{4}, \mathrm{~K}_{5}, \mathrm{~K}_{6}, \mathrm{~K}_{7}, \mathrm{~K}_{9}>0$ and $\mathrm{K}_{1}, \mathrm{~K}_{8}$ and $\mathrm{K}_{0}<0$.

\section{RESULTS AND DISCUSSION}

\section{Socio- Economic characteristics of commercial poultry eggs farmers}

The socio- economic characteristics of the poultry eggs farmers were presented in Table 1 . The result shows that majority of the farmers were males $(64.26 \%)$ and only $35.74 \%$ were females. This shows that male gender is predominant in poultry egg production in the study area. The highest proportions of the farmers (44.68\%) were within the age range of 56-65 years, while the least proportion (1.28\%) were within the age range of 26-35 years and above. This shows that majority of the farmers were advanced in age and almost retirees from active employment and wish to establish the venture to generate secondary income.

Table 1: Social Economic Characteristics of Poultry Eggs Farmers ( $=235)$

\begin{tabular}{|c|c|c|}
\hline Variables & Frequency & Relative frequency \\
\hline \multicolumn{3}{|l|}{ Age } \\
\hline $26-35$ & 3 & 1.28 \\
\hline $36-45$ & 51 & 21.70 \\
\hline $46-55$ & 67 & 28.51 \\
\hline $56-65$ & 105 & 44.68 \\
\hline $66-75$ & 9 & 3.83 \\
\hline \multicolumn{3}{|c|}{ Level of Education } \\
\hline Non-formal & 12 & 5.11 \\
\hline Primary & 33 & 14.04 \\
\hline Secondary & 98 & 41.70 \\
\hline Tertiary & 92 & 39.15 \\
\hline \multicolumn{3}{|l|}{ Experience } \\
\hline $1-8$ & 54 & 22.98 \\
\hline $9-16$ & 15 & 6.38 \\
\hline $17-24$ & 139 & 59.15 \\
\hline $25-32$ & 21 & 8.94 \\
\hline $33-40$ & 6 & 2.55 \\
\hline \multicolumn{3}{|c|}{ Household size } \\
\hline $1-3$ & 30 & 12.77 \\
\hline $4-6$ & 129 & 54.89 \\
\hline $7-9$ & 76 & 32.34 \\
\hline \multicolumn{3}{|l|}{ Farm size } \\
\hline$<200$ & 55 & 23.40 \\
\hline $201-400$ & 125 & 53.19 \\
\hline $401-600$ & 39 & 16.60 \\
\hline $601-800$ & 9 & 3.83 \\
\hline $801-1000$ & 7 & 2.98 \\
\hline \multicolumn{3}{|l|}{ Gender } \\
\hline Female & 84 & 35.74 \\
\hline Male & 151 & 64.26 \\
\hline
\end{tabular}

Source: Field Survey, 2018 
Distribution of farmers according to educational level shows that the highest proportion $(41.70 \%)$ had secondary education and the least proportion $(5.11 \%)$ had primary education. This is an indication that majority of the farmers were holders of secondary school leaving certificates and only few $(5.11 \%)$ had first school leaving certificate that were involved in poultry eggs production in the study area. Majority (54.89\%) of the respondents had family size that ranges between $4-6$ persons while the least $(12.77 \%)$ had family size of household size of between $1-3$ persons. The poultry husbandry experience distribution of the respondents' shows that (59.15\%) had between $17-24$ years while the least (2.55\%) had experience of between 33 - 40years. The flock size which is an indication of scale of production of the study showed that $53.19 \%$ of the farmers had between 401 - 600 birds; while only 2.98\% had between 800 to 1000 birds; This showed that all the poultry farmers are small scale holder and it agreed with the classification of Okpeke (2015), which classified small scale poultry farm as having up to 1000 birds.

Table 2 shows the maximum likelihood estimates of the economic efficiency of poultry egg production in the study area.

Table 2: Maximum Likelihood of the Parameters of Economic Efficiency Functions

\begin{tabular}{|c|c|c|c|}
\hline Variables & Coefficient & Standard-error & t-ratio \\
\hline \multicolumn{4}{|l|}{ a. General model } \\
\hline Constant & 1.6510 & 0.0224 & 73.6914 \\
\hline Flock size & 0.6140 & 0.0051 & $120.2925^{* * *}$ \\
\hline Cost of feed & 0.0114 & 0.0144 & 0.7954 \\
\hline Wage rate & 0.0024 & 0.0068 & 0.3550 \\
\hline Cost of drugs & 0.0055 & 0.0035 & $1.5798^{*}$ \\
\hline Depreciation & 0.3675 & 0.0175 & $21.0336^{* * *}$ \\
\hline Sigma-squared $\left(\sigma^{2}\right)$ & 0.0010 & 0.0002 & $4.1481^{* * *}$ \\
\hline Variance ratio (Gamma $(\gamma))$ & 0.6500 & 0.2636 & $2.4659^{* *}$ \\
\hline Log likelihood function & 81.9203 & & \\
\hline \multicolumn{4}{|l|}{ b. Inefficiency model } \\
\hline Constant & 0.3722 & 0.3724 & 0.9993 \\
\hline Access to credit & -0.2781 & 0.0348 & $-7.9932^{* * *}$ \\
\hline Age & 0.0505 & 0.0108 & $4.6954^{* * *}$ \\
\hline Educational level & -0.0315 & 0.0219 & -1.4379 \\
\hline Farm experience & -0.1033 & 0.0118 & $-8.7336^{* * *}$ \\
\hline Extension contact & -0.0519 & 0.0672 & -0.7720 \\
\hline Flock size & -0.0005 & 0.0001 & $-5.2156^{* * *}$ \\
\hline Gender & 0.0078 & 0.0617 & 0.1270 \\
\hline Household size & 0.0448 & 0.0105 & $4.2852^{* * *}$ \\
\hline Memb. of coop & -0.0005 & 0.0721 & -0.0071 \\
\hline$R$-squared & 0.7445 & & \\
\hline Adjusted R-squared & 0.6713 & & \\
\hline S.E. of regression & 0.2545 & & \\
\hline Durbin-Watson stat. & 1.7435 & & \\
\hline F-statistic & 23.0756 & & \\
\hline
\end{tabular}

Source: Field Survey, 2018
$*$ = significant at $10 \%, * *=$ significant at $5 \%, * * *=$ significant at $1 \%$

The table indicates that the coefficients of flock size (0.6140), cost of feed (0.0114), cost of drugs $(0.0055)$, wage rate $(0.0024)$, and cost of capital/depreciation (0.3675). However, only flock size, cost of drugs and capital were significant determinants of cost efficiency of egg production at $10 \%$ level of significance in the study area. The coefficients of flock size, feed 
intake, medication and vaccination, and cost of capital had positive signs which imply that they have positive relationship with cost efficiency. Thus, an increase in the use of these variables would lead to an increase in cost efficiency by the farmers thereby leading to balanced diets and healthy people. The sigma squared $\left(\sigma^{2}\right)$ of 0.0010 for the commercial poultry farmers were statistically significant and different from zero at $1 \%$ level of significance. This shows a goodness of fit of the model and the correctness of the specified distributional assumptions of the composite error term.

The ratio of the likelihood function, which determines the effect of efficiency parameters on the outputs of farmer, was estimated to be 81.9203 . The variance ratio $((\gamma))$ estimated as 0.65 for the farmers were significant at $1 \%$ level which implied that about $65 \%$ variations in the cost efficiency of the farmers were due to the inefficiency factor ( $\mu$ i). Simply put, variations in the cost inefficiency of the farmers were due to inadequate allocation and utilization of production inputs and not due to random or stochastic error. The results of the diagnostic statistics confirm the relevance of the SFPF using the Maximum Likelihood Estimator. The result compares favourably with the findings of Okpeke (2015).

The analysis of the inefficiency model in (Table 2) shows that the signs and significance of the estimated coefficients in the inefficiency model have important implications on the economic efficiency of the farmers. The coefficients of age of farmers and household size were positive, indicating that these variables led to increase in economic inefficiency while the coefficient of the access to credit, farm experience and flock size were negative indicating that these variables led to decrease in economic inefficiency. Age contributed positively to inefficiency because the older the farmer the less efficient supervision-wise. Also, the Inefficiency parameters establish the fact that inefficiency of poultry egg production increased with increase in family size. This may be due to the fact that cost of living would increase with more dependants in the family.

Also, it is in line with the a- priori expectation that economic inefficiency should decrease with increase in years of experience, access to credit and flock size since these variables are expected to be positively correlated to adoptions of improved technology and technique of production since there is available capital, experience to manage a commercial based farm and such large farm with increased flock size would enjoy benefits of economies of scale (Ojo and Ajibefun, 2000 and Okpeke, 2015). Experienced farmers who have access to credit tends to commercialize their farms for economies of scale such as reduction in costs of feeds, drugs, medication and other inputs per bird stocked which led to increases economic efficiency.

The result of the frequency distribution of economic efficiency estimates in Table 3. It shows that the economic efficiency estimates for poultry egg producers ranged from 0.224 to 0.987 with mean value of 0.560 and this shows that the distribution seemed to be skewed toward the frontier as it is very close to 1.00 . The minimum economic efficiency was 0.224 indicated high level economic inefficiency while the maximum economic efficiency score was 0.987 , implying that the most efficient processors operated almost on the frontier with the mean of 0.560 with indicated the frontier levels in the area. This indicated poultry egg producers require improvement of $44.0 \%$ in their resource use to attain $100 \%$ economic efficiency. The result shows further that $54.89 \%$ of the egg producers are below frontier level, Also average egg producer needs a cost savings of $43.26 \%$ (i.e, $1-0.560 / 0.987$ )*100 to attain the status of the most economically efficient producer. 
Table 3: Economic Efficiency Distribution of Respondents

\begin{tabular}{lcc}
\hline Economic Efficiency Index & Frequency & Relative Frequency \\
\hline $0.101-0.250$ & 13 & 5.53 \\
$0.251-0.450$ & 111 & 47.23 \\
$0.451-0.600$ & 50 & 21.28 \\
$0.061-0.750$ & 1 & 0.43 \\
$0.751-0.900$ & 2 & 0.85 \\
$>0.900$ & 58 & 24.68 \\
Total & 235 & 100.00 \\
Mean & 0.560 & \\
Min & 0.224 & \\
Max & 0.987 & \\
\hline
\end{tabular}

Source: Field Survey, 2018

\section{SUMMARY, CONCLUSION AND RECOMMENDATION}

Flock size, costs of drugs and capital (depreciation) were significant factors of cost efficiency of the poultry egg farmers. The sigma squared $\left(\sigma^{2}\right)$ of 0.001 for the poultry farmers were statistically significant and different from zero at $1 \%$ level of significance. This shows a goodness of fit of the model and the correctness of the specified distributional assumptions of the composite error term. The variance ratio $(\gamma)$ estimated as 0.65 for the farmers were significant at $1 \%$ level which implied that $65 \%$ variations in the cost of production of the poultry egg farmers were due to the inefficiency factor $(\mu \mathrm{i})$. Simply put, variations in the output of the farmers were due to inadequate allocation and utilization of production inputs and not due to random or stochastic error. The mean economic efficiency was 0.560 and ranges between 0.224 and 0.987 . The coefficients of age of farmers and household size were positive, indicating that these variables led to increase in economic inefficiency in economic efficiency of egg production in the study area. The coefficients of years of access to credit, farming experience and flock size were negative and significant at $1 \%$ level of significance.

It can therefore be recommended that capital should be channeled to commercial poultry production through the provision of macro-credits and formulation of policies and programmes by the Government to direct financial institutions to grant a definite reasonable proportion of loan-able funds to commercial poultry farmers. Potent medicine and vaccine should be provided in sufficient quantities, easily accessible. Poultry equipment manufacturers should be encouraged by the Government with provision of credit facilities and subsidies in the study area.

\section{References}

Adedeji, I.A., Adelalu, K.O., Ogunjimi, S.I. and Otekunrin, A.O.(2013) Application of Stochastic Production Frontier in the Estimation of Technical Efficiency of Poultry Egg Production in Ogbomoso Metropolis of Oyo State, Nigeria World Journal of Agricultural Research, 1(6): 119-123 DOI:10.12691/wjar-1-6-5

Adetimirin, O.T. (2000). “Analysis of Egg Marketing in Agege Local Government Area of Lagos State”. Unpublished B. Tech Thesis, Department of Agricultural Economics and Extension, Ladoke Akintola University of Technology Ogbomoso.

Ali, M. A. (2002). “Inter-Regional farm efficiency in Pakistan's Punjab”. A frontier production function study. Journal of Agricultural Economics, 41(1): 16-18.

Binuomote, S.O., Ajetunmobi, J.O. and Ajao, A.O. (2008). "Technical Efficiency of Poultry Egg Producer in Oyo State of Nigeria". Int. J.Poultry Sci. 7(12):1227-1231.

Coelli T.J., (1996) A guide to frontier 4.1: A Computer Programme for Stochastic Frontier Production and Cost Function Estimation. Working Papers 7/96. Department of Economics, University of New England, Armidale, NSW 2351, Australia; 1996. 
Conroy C., (2005) Why Livestock is important to resource poor people."Participatory Livestock Research: A Guide. Published by Intermediate Technology Development Group (ITDG), Great -Britain 3-5.

National Population Commission (NPC), (2006): NPC Releases 2006 population figures. Available online at http://www.nigeriavillagesquare.com/articles/nvs/npc-releases-2006-population-figures-14.html assessed on $13^{\text {th }}$ July, 2016

Ogundari K., (2006). Determinants of Profit Efficiency among Small Scale Rice Farmers in Nigeria. Paper Presented at the International Association of Agricultural Economists Conference, Gold Coast, Australia.

Ojo, S.O. and Afolabi, J.A., (2009) Economic Analysis of Replacing the fish meal Component of Broiler Starter mash (Glincidia Sepium). Animal Production in the New Millennium, Challenges and Options. Book of Proceeding. Edited by Ukachukwu, S.N; 2009.

Ojo, S.O. and Ajibefun, I.A.(2000). Effects of Training on Labour Productivity and Efficiency in Oil Palm Production in Ondo State, Nigeria. J. Sustainable Agri. and Environ. 2: 275-279.

Okpeke, M.Y, (2015) Application of a stochastic frontier production function to the measurement of technical efficiency of commercial Poultry egg production in Nigeria Global Journal of Agricultural Research 3(4): 1 - 11 